\title{
African Indigenous Proverbs and the Institutional and Pedagogic Relevance for Youth Education: Lessons from Kiembu of Kenya and Igbo of Nigeria
}

\author{
George J. Sefa. Dei (Corresponding author) \\ Dept. of Humanities, Social Science and Social Justice Education, OISE, University of Toronto, \\ 252 Bloor St W, Toronto, ON M5S 1V6. E-mail: george.dei@utoronto.ca
}

Received: September 17, 2013 Accepted: October 12, 2013 Published: December 9, 2013

doi:10.5296/jet.v1i1.4708 URL: http://dx.doi.org/10.5296/jet.v1i1.4708

\begin{abstract}
This paper raises fundamental questions about struggles of Indigenous philosophies and the ways educators can teach multiple bodies of knowledge to enhance youth education. It adopts a comparative approach to the study of African proverbs focusing on two communities highlighting the points of convergence [and divergence] in their cultural knowledge systems. Within the African traditional context proverbs as a way of knowing are deeply embedded in the community's cultures, histories, Indigenous cosmologies and worldviews.
\end{abstract}

Keywords: African indigenous proverb, youth education, indigenous knolwedges, pedagogical implications

\section{Introduction}

This paper raises fundamental questions about struggles of Indigenous philosophies and the ways educators can teach multiple bodies of knowledge to enhance youth education. It adopts a comparative approach to the study of African proverbs focusing on two communities highlighting the points of convergence [and divergence] in their cultural knowledge systems. Within the African traditional context proverbs as a way of knowing are deeply embedded in the community's cultures, histories, Indigenous cosmologies and worldviews. African proverbs are about relations between individuals and their communities, an understanding of the complex nexus of society, culture and Nature, as well as the interconnectedness of body, mind, soul and spirit. Understanding the ways proverbs can be evoked in everyday conversations and community living points us to the cultural values, social norms and ethics/morals are rewarded/privileged/honored and impacted to the youth who become responsible adults. Like all knowledge systems, proverbs contain sites of empower and disempowerment for communities. For example, there are proverbs that can be demeaning to 
women, ethnic and linguistic minorities. Some proverbs can be used to justify patriarchy and other social oppression, especially those proverbs that uncritically uphold tradition and custom. The learning objective in this paper is not to gloss over these uncomfortable knowings. My intent instead to highlight the positive (i.e., solution-oriented) aspects of proverbs as epistemologies with practical and useful teachings to youth. I offer lessons of African proverbs as a corrective to help address some of the contemporary social ills (e.g., youth indiscipline, lack of respect to self and others, including Elderhood, insubordination and societal violence). The question of how we come to understand the causes of these social problems is a different discussion this paper does not indulge in. However, the paper makes the case that the young in local communities may at times exhibit certain behaviors that ran contrary to acceptable societal norms and culturally legitimated teachings. This is in part because of the nature of family and community socialization that is not rooted in the values, social norms and ideals that stress harmony, fairness, equity, appreciation of oneself and others, co-existence, responsibility and justice.

I would caution against strictly evaluating the merits of Indigenous philosophies within dominant paradigms and standards as to what constitutes acceptable knowledge and how such knowledge should be produced and legitimated. This paper does not set out to test any hypothesis nor make any effort to test or sample at random the utility of various pieces of Indigenous knowledges. The objective is to understand the particular teachings contained in local African proverbs and how educators can work with these bodies of knowledge. The discussion is informed by a simple question: What is the role and place of Indigenous philosophies (e.g., proverbs) in the pursuit of socially transformative education? There are changing and emerging trends in proverb scholarship that are greatly impacting the way African proverbs are perceived in the [Western] academy and the wider society. For example, proverbs constitute Indigenous knowledge with lesson for multi-centric and polycentric ways of knowing. In other words, proverbs challenge dominant Eurocentric ways of knowledge production by working with such ideas of holism and holistic education, the intellectuality of emotions, spirituality and spiritual knowings, and the power of relations of the learner to the Land on which they study. Proverbs also challenge the way we do education. Through time the status of proverbs in African societies has soared as their engagement in everyday conversation show deep intellectual depth and thinking of Elders, adults or youth who lace their everyday conversationd with proverbs. While African proverbs have been extensively researched and analyzed, the question of how proverbs offer critical pedagogic, instructional, and communicative relevance for youth education in pluralistic societies has only been sparsely addressed. Every knowledge production is science. Science is thus a human enterprise and belongs to all. The science of Indigenous knowledge production is foundational to understanding the social, spiritual, metaphysical and physical worlds of Indigenous peoples. In effect, all humans are theory builders. We each live with ideas and theoretical frameworks or prisms. There is an African Indigenous that is rooted in long-term knowledge held over Land, space and territory as part of both broken and unbroken residence. Today, what our youth need most is education that is rooted in the Land and Soil/Earth and the particular teachings that make life work living, sustainable and relevant. 
In working with Indigenous African proverbs we are dealing with the corpus of knowledge which can allow for an understanding of the multiplicity of conceptions of African 'worldsenses' and ideas about humanity. Such proverbs constitute knowledge not only for African peoples but knowledge for the global public sphere. The engagement of local proverbs, cultural stories, songs, riddles, folktales, myths and mythologies in what can be called the "pedagogic and instructional acts of Indigenous story telling" as part of the everyday school curriculum [as broadly defined] can help educate young learners to appreciate themselves and to encourage social responsibility, ethics, and community belonging. Proverbs (like other forms of Indigenous philosophies such as cultural stories, riddles, folktales), reveal the power of learning communities characterized by resilience, resistance, creativity, resourcefulness, responsibility, stewardship, and vulnerability. Proverbs constitute an integral part of Indigenous social learning, critical teaching and educating about self, group, society and nature. Proverbs also speak to acts of reconciliation and knowledge reciprocity, and the coming to terms with expectations of daily existence. Opening up space through the telling of Indigenous proverbs (including stories, songs, riddles, folktales etc) is not simply an act of self and group determination, but more importantly, also a form of cultural expression of Indigenous peoples' to reveal deep concerns about and appreciation of knowledge, dialogue, representation, questions of legitimation, validation, appropriation, reciprocity and social accountability (see also Bishop, 1999; Haig-Brown, 2003 in other contexts).

It is contended that while the engagement of local cultural resource knowledge has not been prominent in providing options for youth, this can be an important tool in educational delivery. Consequently, the identified teachings of Indigenous African philosophies such as cultural stories, songs and proverbs relate to the concept of self and the community, responsibility, respect for oneself, peers and authority, and mutual interdependence and community building while speaking to their place in school curricular, pedagogical and instructional initiatives to enhance youth learning.

There are pertinent questions and issues about culture and the importance of local cultural knowings such as Indigenous proverbs, folktales and songs in informing and framing curriculum, instructional and pedagogical practices around moral and civic education. These concerns also have educational policy implications as educators and administrators search for ways to promote inclusive learning spaces that ensures that the youth develops a sense of connectedness and responsibility to their communities. Through the emphasis on the role of Indigenous knowings in civic, moral and character education, this paper is intended to provoke critical thought about the mission of schooling and education in contemporary contexts. For example, how do we [as educators and administrators] provide education to young learners in ways that allow them to develop a strong sense of identity, self and collective respect and empowerment to community building? How do we empower young learners to make their school learner-friendly? How do learners in schools cultivate an understanding of 'schooling as community' or work to create schools into "healthy, working communities"? How do we collectively subvert colonial relations, hierarchies and agendas of schooling beyond concerns about "managing [school] discipline" and empower the learner of 
today to be socially responsible to their communities?

These are not questions that are easily answered. However, through a critical reading of the connections of culture, pedagogy and classroom instruction, the paper will situate the task of creating schools as working communities while fundamentally challenging us to rethink the structures of educational delivery (i.e., structures for teaching, learning and administration of education). Culture is a contested notion. Culture epitomizes a people's expression of their material, non-material and ideational belief systems. Culture is about the organization of communities and the particular social arrangements that allow the everyday actualization of a people's hopes, dreams and experiences. The material and non-material aspects of culture work in tandem to provide social cohesion to communities in terms of the organizing principles, ideas and beliefs that shape everyday practice and social action. Culture is taught through everyday socialization processes. The values, social norms and etiquette of a community are passed on intergenerationally through everyday teachings of culture. Through the socialization of youth, knowledge about community belonging, the understanding of the self and relations with others, respect for self, peers, authority, importance of personal character and moral discipline are all passed on through cultural teachings. Such knowledge, transferred from adult to the young, reinforces both the relevance and link of the culture, pedagogy, and education. Knowledge is embedded within particular cultural contexts and the pedagogic relevance in cultural teachings is shared with young learners to emphasize our shared humanity and our obligations and expectations of belonging to groups and communities, even as we claim our individual identities. Cultural tools as part of a community's knowledge system are taken up individually in society to mediate the formulation of a collective memory. Proverbs as part of the cultural knowledge system thus embodies a peoples' cultural memory. Within a given community, individuals and groups employ culture and cultural tools to mediate the complex interactions between themselves and their social, cultural, and historical communities. As proverbs teach about morals and character, they serve to regulate social action and human behavior in societies. Thus culture is the starting point for discussion of knowledge production, identity, and development. It is the complex engagements of the individual within and with the dynamic entity of culture that shapes who they are and how they come to know the world (De1, 2013a; and also, some of the early psychological, sociological and/or anthropological writings of Clifford, 1986; Geertz, 1993; Rogoff ,1981, 2003; Wertsch, 1985, 2002; Tappan, 2006; Cole 1992, 2006).

The engagement of local cultural knowings reflects the power of culturally-contextualized discourses to transcend geographical/physical borders and boundaries in the delivery of effective education to young learners. African proverbs have universal teachings that can be useful to young learners everywhere. In fact the same can be said of all proverbs from global communities. These knowledges can be shared and specific classroom instructional practices can be put in place for youth to use them to improve upon their own learning and social life. While these knowledges derive from particular cultural contexts, their teachings have lessons that are widely applicable in a variety of contexts and circumstances provided the educator is able to draw out the teachable components for school learners.

A focus on a descriptive and analytical discussion on Indigenous African proverbs drawn 
from Kenya and Nigeria offers some useful directions on the key educational issue of responsibility for one's learning and community building. In fact, teaching about community and our mutual interdependence could be a good starting point in the education of the young learner today. So we must ask: What can be learned and how can we tap from local cultural resources knowledges for their curricular, pedagogic and instructional interventions in order to build a moral and social backbone for young learners? How can conventional educational system develop effective ways to address the alienation of young learners? How can we strengthen current educational practices and interventions already in place in schools and promote new educational initiatives (curriculum, pedagogy and instruction) to ensure a genuine inclusiveness of all youth? I would argue that perhaps foregrounding local cultural resource knowings may be an important key for tracking the effectiveness of educational teachings about respect, self worth and discipline methods, including those derived from local Indigenous philosophies focusing specifically on values and character education.

As already noted elsewhere (Dei, 2013a, b) Indigenous stories, songs, proverbs and folktales are Indigenous ways of knowing. They are knowledeges that present a philosophy of life, wise sayings used to teach youth about life, allowing them to grow mentally, spiritually, morally into adulthood. The individual grows up responsibly through the advice contained in proverbs and riddles. As a form of communication, proverbs provide forums of socialization of youth around the genders, ethnicities, ages, and other affiliations. Proverbs help keep communities and peoples together. In African contexts there is a growing body of works that have documented Indigenous proverbs, fables, parables, tales, mythologies and their cultural meanings and interpretations (see, for example, Kudadjie, 1996, Yankah, 1989; 1995; Opoku, 1975, 1997; Ogede, 1993; Kalu \& Ogbu, 1991; Pachocinshi, 1996; Abubakre \& Reichmuth, 1997). Many Indigenous communities elsewhere also utilize proverbs, parables, folktales and mythologies to convey meanings of society, nature and cultural interactions (see Abrahams 1967, 1968a, 1968b, 1972; Dorson, 1972; Taylor 1934; Wolfgang and Dundas 1981). We know that Aboriginal traditions focus more on storytelling than proverbs and fables. Yet, in Aboriginal epistemology, we see how story telling conveys powerful meanings similar to those encoded in proverbs, parables, fables, and tales in other Indigenous contexts (Firth, 1926). Within the stories, a critical learner can get a powerful sense of the pedagogic, instructional and communicative relevance of such cultural knowledge. For example, Johnson (1993, 2003) shows Ojibway mythology as rich, complex and dense meaning and mystery. His works provide readers with a succinct understanding of Ojibway people's life, legends, and beliefs. Like stories and mythologies, proverbs when told often evoke an act of self-reflection from the learner/listener. As powerful knowledge forms, proverbs, folktales, and stories offer a deeper level of understanding and appreciation of the community's place in the larger social, physical, and cultural realm of life. As the writings of Chamberlain (2003), Eastman and Nerburn (1993) and Stiffarm (1998), among many others, point out in the current globalized and transnational world where 'migration, Diaspora, and resettlement are everyday affairs' and where we continually encounter competing claims to land, resources, knowledge and power; proverbs, tales, folktales and mythologies [even when contained in stories] can be helpful to all learners in appreciating the common thread of human existence. 


\section{Study Context and Method}

Since 2007-8, I have been involved in an on-going longitudinal study in Ghana, Nigeria and Kenya examining Indigenous African philosophies (particularly examining how cultural knowledge systems are entrenched in local proverbs, songs, folktales and story forms) for their pedagogic and instructional relevance in youth education._Funded through a contract grant from the Ontario Literacy and Numeracy Secretariat, the initial 2007-8 study was entitled 'Moral and Character Education in Ontario: Learning from African Proverbs' focusing on Ghana and Canada' (see Dei, 2010). Due to the success of the pilot study and through funding from the Social Sciences and Humanities Research Council (SSHRC), the initial study was extended to encompass field documentation of local proverbs in Ghana, Kenya and Nigeria, while at the same time working with Canadian educators to highlight the pedagogic, instructional, communicative values in youth education. Between 2007-9, over a dozen (12) focus group discussions were conducted alongside workshop sessions with student-educators, field practitioners and educationists drawn largely from Ghana and, to some extent, Nigeria and Kenya. During this period, a total of over eighty-five (85) individual interviews were conducted with twenty-five (25) educators, twenty (20) Elders/parents, and twenty-five (40) students drawn from the local universities, secondary schools and community colleges, as well local communities._

From 2009-2012, the research has continued in Nigeria, Kenya and Ghana encompassing a content analysis of library documents and archival collections on Nigeria, Kenya and Ghanaian Indigenous cultural knowledge systems (e.g., parables, proverbs, riddles, songs, folktales and other folkloric production). Beginning in July 2012, I worked with local undergraduate assistants and research consultants in Nigeria, to commence extensive interviews with at least 10 Elders (as cultural custodians), 20 educators and 20 students at the Adeniran Ogunsanya College of Education in Otto/Ijanikin, Lagos State, and Lagos State University, Lagos, Nigeria. This part of the study also encompasses classroom observations of educators who had been selected for interviews at the two institutions and a series of focus group discussions with educators and students. During the summer of 2012, the on-going study concentrated on basic/elementary education, vocational training/polytechnic, and community-based cultural activities contributing to the local cultural socialization and education of youth in Kenya. This phase of the fieldwork also involved an initial study of the literature on local proverbs, folktales, songs and other folklore at local universities in Kenya, specifically, The University of Nairobi and Egerton University in Egoro, Nakuru district. Community Elders and parents as well as 10 students at the basic/elementary school level, and 10 students at a vocational/polytechnic training institute in the Embu district of Kenya were interviewed. Educators at the Kenyan institutions mentioned above were also interviewed; including focus group discussions and workshops with study participants. I was fortunate to have trained research assistants documenting proverbs, riddles and folktales provided by Elders in the local languages with translations in English. The focus of this work has been to comprehend the use and meanings of local proverbs and their instructional, pedagogic and communicative values, particularly focusing on the teachings about identity, self-worth, respect for self, peers and authority and the obligations and responsibilities of 
community belonging.

\section{Selected African Indigenous Proverbs}

In the preceding section I discuss proverbs of the Kiembu of Kenya and Igbo of Nigeria pointing to their pedagogic and instructional relevance in the education of young learners as responsible adults.

\subsection{Kiembu of Kenya Proverbs}

\subsubsection{Kimba kia muthoni na muthoni kigucaga vamwe.}

\section{[In laws live together and die as friends].}

We create communities for life not simply for convenience. This is about the responsibilities of life. When people join together as family they become friends forever. Death does not sever such ties. This proverb is about the importance of teaching about family, community and responsibility. For example, family is family and family members will always remain friends because of mutual obligations and expectations that arise of a union (e.g., marriage and bringing forth children). Children unite families and people create communities. One can never be enemies forever when families and communities have been created. Pedagogically, the proverb can be engaged to teach youth about community building, the importance of remaining true to friends and even what one perceives as enemies and the responsibilities to each other when families and communities are created.

\subsubsection{Kava ndaca ikinyia}

\section{[Short cuts are not always the safest].}

This proverb implies that things are not always simple. There are no quick fixes in life. Sometimes taking the easy way out may seem convenient but it is ridden with woes and troubles. One must take time, diligence and patience to pursue their life goals and ambitions. Hard work bears fruits and has results beyond the immediate quick gratification. Laziness is not a virtue. It is a risky undertaking. Anything that is seductive and appealing has cautions and risks attached. Pedagogically, this proverb can be used by the classroom teacher to teach youth to be careful of your life. Life is delicate and must be protected through hard-work, self determination and long pursuit of happiness. Nothing comes easily in life. Success acquired through quick and easy fixes is always very flimsy. The student must learn to work long, hard and with proven and tested determination to secure success. Such success tends to be long lasting and rewarding.

\subsubsection{Njamba ti ikere}

\section{[Don't undermine a weak person because he can do great things].}

This proverb is to instruct the young about ethics, social responsibility and humility. The teaching is that no one is dispensable and also indispensable at the same time. Good and indeed great things can be accomplished by everyone so far as one has set goals, perseverance and determination. The 'weak' person is not immune to acquiring success and 
reaching great heights in life. We all need to show determination to succeed even against tremendous odds. The proverb also teaches about our responsibilities to each other and to show gratitude, respect and tolerance of others as we never know what the future holds. We should always be careful of our actions as they tend to have future repercussions. So we must all be supportive of each other. Within each of us, we have skills, capabilities and talents to success and accomplish greatness. Failure is not an option. We all have responsibilities to help one another acquire success and that it is the most successful, brightest, powerful and strong who have a particular responsibility to assist the weak, less fortunate and disadvantaged. Ethically we must all have a good heart and be humble in our claims of strengths and accomplishments.

\subsubsection{Gutiri iri kavici itagakomwa ruaru}

\section{[Where there is a baby boy there is a better future in that home].}

This proverb was used traditionally to teach that the young are full of promise. The birth of a child is a time for joy, celebration and peace. It is the beginning of a bright future and promise of greatness. But the proverbs has also be contextualized and problematized in a gendered reading where in traditional communities the male child was seen as the breadwinner and therefore full of promise. Thus, the teaching of the proverb was that the future is for the newly-born male child to conquer. The family rejoices more so when a baby boy is birthed. The proverb can be engaged pedagogically to teach about gender and patriarchy, as well as hope and promise at the same time. Its gendered connotation in terms of upholding the male child to future promise should be troubled and critically discussed with young learners. The educative potential and message is for all youth. There is hope and promise for the youth. But such hopes and future aspirations must be cultivated and well-nurtured. They must also be captured with collective efforts. Through family support and determination the youth can be assisted to create their own futures and dreams.

\subsubsection{Icoya ritheka mwagau}

\section{[It is a young person who laughs an old one]}

The young while full of hope and determination can also be innocent and misinformed. They may lack some knowledge about life experiences and shows this by disrespect for the Elderly and the aged. Anyone who fails to recognize the wisdom and knowledge of the Elderly is not only misinformed but shows a great deal of youth and immaturity. The proverb teaches about the importance of knowledge, social maturity and respecting the aged and the elderly. Anyone who fails to exhibit such traits of character is a child and immature. They are never adults. Therefore, the purpose of this proverb is to teach about respect for oneself, peers, Elders and authority. It teaches about self-discipline, understanding one's identity and relations to others in a community. Life influences and decisions are determined by our choices. It also teaches about responsibility of adults and the aged. Children need good counseling and guidance when they are young. As adults it may be difficult to bring them to a good path, but through our actions and deeds the youth will come to appreciate our lives and seek to emulate our worthy examples. Any person who refuses to be advised will have problems later as they 
remain in perpetual stage of a child who has never grown up.

\subsection{Igbo of Nigeria Proverbs}

\subsubsection{Ite belu ugwu ejula eju}

[It is a pot of water that is already half full that the world would like help in filling to the brim]

The half-filled pot is almost full, implying when used in Igbo, that it is easier to help one who has made sufficient efforts than one who has made none. This proverb suggests that the world is more willing to help those people who help themselves. In other words, if one is too lazy to do any work then others will also be too lazy to help you out. In terms of education, this proverb could be taken to suggest that teachers will be more interested in teaching those students who are willing put in some efforts of their own into their education. But a critical pedagogic engagement of this proverb is also required form a teacher. For example, while the proverb is certainly note-worthy and greatly applicable to our educational system, it also places a great deal of the responsibility of success on the student's shoulders. It fails to consider questions of equity, such as: are all students equally equipped to put their best efforts into scholarly matters? How do we account for differences in access, abilities, and learning styles? Should teachers only be motivated to teach students who are motivated to learn? Asking such questions contributes to the educative potential of the proverb for the contemporary learner, raising questions about responsibility, ethics and equity as equally important in discussions about roles and expectations of youth.

\subsubsection{N'ugbo onye huru onwe ya ka ona anya}

\section{[One must row in whichever boat one finds one's self]}

Literally the teaching of this proverb says one rides in the boat one finds oneself, i.e., one makes use of resources or adapts to her/his inevitable circumstances. Igbos believe that only Chukwu or Chineke (Almighty God or God the Creator) respectively design a person's destiny, so each person makes do with whatever the Creator bequeaths to her/him. The proverb is interesting as it suggests that no matter what adverse conditions we may find ourselves in, the only intelligent thing to do is to deal with the situation and make the best of it. Thus, one is advised not to complain and lament over a bad situation, but to make the most of what is given to us in life. In relation to education, the teachings of this proverb can be engaged by the classroom teacher to call for positive thinking and actions on the parts of students who may find the school curriculum or student-life too difficult to handle. The proverb suggests that students should not give up. Instead, they must make the best of difficult situations. It also suggests that, for example, instead of complaining over poor grades or bad instructors, they should make the best of their situation, and in doing so, try to turn it around into a positive experience. Again, a critical pedagogic engagement of the proverb is also called for in order for youth to engage with their critical and questioning minds. For example, in teaching this proverb to students, the teacher can also stress that it is not always enough to simply make the best of a situation. Learners should also place importance on recognizing bad situations, and working on correcting them by either complaining or actively 
working against them. This is teaching about responsibility.

3.2.3 Nwayo nwayo k'eji ara ofe di oku

\section{[Hot soup is eaten gradually and in stages]}

The teachings of this proverb emphasizes that one accomplishes an enormous task gradually and in stages. The proverb is similar to the adage: 'slow and steady wins the race'. It means that an enormous task is accomplished when tackled patiently but consistently. This adage suggests that it takes patience and dedication to achieve one's goals in life. When evoked in classroom teaching and education, the proverb suggests to students that it takes steady and constant hard work to make gains, both in studies and in life. The proverb can also be taken to suggest or teach that quick and easy ways of making gains (such as cheating etc.) are neither reliable nor noble, and real success comes to those who are willing to work hard and persevere. Students can be educated about the benefits of humility and patience and not to expect success instantly. Success [both social and educational wise] calls for hard work, dedication and diligence. Success is patiently cultivated and it is the one willing to work patiently that gains such social and educational success.

\subsubsection{Agba mbu otu n'ogwe, agba abuo otu n'ogwe, obuzi ogwe k'apiri aku}

\section{[A hunter who has only one arrow does not shoot with careless aim]}

An Igbo would ask: if one shoots the first time and it hits the stem, and the second arrow goes the same way, is the arrow crafted for the stem or what? The implication is that one must be careful using her/his scarce resources otherwise it will all get aimlessly used up. Arrows are meant to hit their targets (games) during hunting, not tree stems. Since the arrows are always few in their sheath, each requires absolute care when aimed in order to hit the target or it is wasted. This proverb suggests that we only get one chance to live, and so it is essential to make thoughtful and correct choices in all aspects of our lives. Particularly in relation to schooling and education often times students only have one chance to choose their desired course of study or profession. Thus, it is very important to be thoughtful and wise while making these decisions which will have a great impact on our lives. An error in such a decision can lead to lost time and opportunity, both of which may never be gained back. So, it is important to make these decisions with the thought and precision used by a hunter who only has a single arrow in his possession.

\subsubsection{Otu ala adighi azu nwa.}

\section{[A child does not die because the mother's breasts are dry]}

One breast does not feed a baby, implying that if a newly-delivered mother's breast runs dry, another mother within her kin whose breast milk is ready continues the duty of nursing the baby. This is teaching about community, responsibility, mutual inter-dependence and the importance of watching each other backs. The proverb also emphasizes the importance of improvisation in one's life. It suggests that, just like a baby without access to breast milk learns to adapt to new foods, so we should also adapt to new situations and not limit ourselves to our comfort zones. As a student, one may not always have the luxury of 
following the exact life-course that was originally planned. Many times, situations cause students to give up on original goals and plans and seek new ones. In such times, it is vital to not give up hope, but rather, consider this new situation as one where one can use creativity and ingenuity to chart a new plan and find a new focus. Thus, a student who is simply unable to achieve his goal with his present strategies should then consider changing these strategies, techniques or goals in order to succeed. This is certainly not to say that one does not need to work hard to succeed (or that if the work becomes too hard, then it is best to drop that path and follow an easier one), but rather, the proverb teaches us that when there are no choices then one has to change her/his plans. We should not be dejected, but rather use it as an opportunity to succeed again.

\section{Discussion}

This paper has highlighted the educative merits of Indigenous African philosophies such as proverbs relating to the concept of self and the community, responsibility, respect for oneself, peers and authority, and mutual interdependence and community building and their place in school curricular, pedagogical and instructional initiatives to enhance youth learning (see Boateng, 1990; and in related context, Abdi and Cleghorn, 2005 (eds). The engagement of local cultural resource knowledge has not been prominent in the search for genuine educational options for youth. And, yet this can be an important tool in educational delivery. The paper has pointed to the pedagogic, instructional and communicative relevance of proverbs for educating young learners need to be fully explored. Proverbs and riddles are Indigenous ways of knowing. They are knowledegs that present a philosophy of life, wise sayings used in teaching about life (see Bascom, 1965; Kudadjie, 1996, Yankah, 1989; 1995; Opoku, 1997, 1975; Ogede, 1993; Abubakre and Reichmuth, 1997; Akporobaro \& Emovon ,1994; Wanjohi, 2001, 2008; Miruka, 2005) to mention a few). Knowing Indigenous proverbs is about power. Proverbs are told to the young to allow them to grow mentally, spiritually, morally into adulthood. They are a form of customary teachings and words of caution, warning and advice that guide social conduct for all including young, adults and Elders. Elders as cultural custodians are generally seen as having a particular responsibility to teach and lead by example through the use and engagement of proverbs. Elders themselves are seen as steeped in a higher sophistication of local knowledge contained in proverbs. Thus, the teachings of such Indigenous/local cultural knowledges require the help of local Elders. In most cases Elders approval must be sought and recognized before the use of proverbs. The individual grows up responsibly through advice contained in proverbs and riddles. As a form of communication proverbs and riddles provided forums of socialization around the genders. They helped keep communities and peoples together. Individuals learn from the example manifested in proverbs, while social gatherings provided avenues for teaching the young. Embedded in African proverbs and riddles are the bonds of African hospitality, generosity and communionship.

Proverbs as part of African Indigenous philosophies contribute to understandings about ways of knowledge production, schooling and education. Like any scientific endeavour, Indigenous philosophies as theory building must seek to establish the basis of a peoples' cosmology/worldview or 'worldsense' (Oyewumi, 1997) the underpinning social values 
system, the method and methodology of coming to understand such knowledges and how we make the bridging of a theory and practice (see also Dei, 2011). These are the conceptual and practical grounds of developing any discursive framework to undergird the study of Indigenous knowledges. Understanding Indigenous philosophies require a frame of reference: the idea of 'society-nature-culture' nexus or interface that ensures the vitality of Indigenous African cultures (see also Dei, 2012). To speak of a world community is to acknowledge the society-nature-culture as in constant union and relations. This interface connects the material and non-material, the social, cultural, as well as the physical and the metaphysical. The society-nature-culture interface speaks of harmonious inter-relations that offer meaning to everyday social existence and the human condition. It can be argued that knowledge is based on observing and experiencing the social and natural worlds and human beings are learners of the social and natural world.

Knowledge is socially and collectively created through the interactive processes between individuals, groups, communities and their natural worlds. Knowledge comes from individual, family, and community interactions, as well as through the interactive processes with nature. In effect, humans are part of the natural world. We do not stand apart and neither are we above the natural world. Thus humans and their culture simply relate to nature and the surrounding environments. The society-culture-and-nature interface also acknowledges that both the social and natural worlds are full of uncertainties, and that there is no certainty in any knowledge. Every way of knowing is clouded by some uncertainty about the social and natural worlds. Humans do not need to strive and explain away everything about their world. In effect, humans do not possess the Earth. It is argued in Indigenous and African cultures that all living beings have borrowed the Earth from the ancestors, and that the living would incur the wrath of the ancestors if they destroyed nature in the process of satisfying societal and individual material needs. Knowledge is about searching for wholeness and completeness. This wholeness is a nexus of body, mind and soul, as well as the interrelations of society-culture-and-nature. To understand is to have a complete, holistic way of knowing that connects the physical, metaphysical, social, material, cultural and spiritual realms of existence.

Indigenous theorizing is about representation and having a voice to tell our own stories and experiences. It is such voices that affirm the vitality of Indigenous cultures. Unfortunately, voices that speak about a peoples' Indigeneity and Indigenous knowings are often muted, silenced and discredited as not worthy of engagement. Usually when counter narratives or anti-colonial theoretical oppositions are voiced, these are often ridiculed as is the case of the subjectification of Indigenous knowledges as "racial subset of knowledge" (Battiste and Youngblood Henderson, 2000). One can only conclude that perhaps reaction to Indigenous knowledge is more a question of how such knowledge reacts with certain bodies (in terms of threatened identities and politics), more so than where such knowledge sits (in terms of whether it is robust, sophisticated or shows theoretical clarity). These knowings are about the creation of community power - how our communities bring their own power, resourcefulness and creativity to solve their own problems. Today we are neither in balance nor in harmony with ourselves and nature. This can happen in part when we are seriously committed to 
knowledge collaborations, working with multiple knowledge systems and creating a synthesis of knowledge that are able to deal with fundamental questions of power.

I would reiterate that the engagement of local cultural resource knowledge has not been prominent in the search for genuine educational options for youth. And, yet this can be an important tool in educational delivery. My paper asserts the educative merits of Indigenous African philosophies such as proverbs relating to the concept of self and the community, responsibility, respect for oneself, peers and authority, and mutual interdependence and community building and their place in school curricular, pedagogical and instructional initiatives to enhance youth learning.

As I have argued elsewhere (Dei, 2013a, b) the cultural knowledges and social values embedded in African proverbs echo values that underpin democratic education and society and challenge the harsh competitive individualist models of learning and success that have been instituted through neoliberal value systems of productivity, consumerism, and efficiency. Among the social values, respect is arguably the most frequently cited in African proverbs. Others include integrity, honesty, responsibility, caring and compassion, co-operation and collaboration (or 'teamwork'), etc. The proverbs discussed in this paper allude to these teachings. The incorporation of such proverbs into school teachings can move schooling-and-education towards a much needed multi-centric/polycentric education model that recognizes different types of learners, their knowledges and experiences and challenges the Eurocentric model of humanism. African proverbs recognize more open concept of morality as being relational and communal, which allows for 'teaching discipline' rather than 'enforcing discipline'. African knowledge and traditional teaching stress the imparting of values that make for "good character", as well as education that focuses on furthering understanding of our worlds. However, there is a question of difference in the core social values privileged between cultures. For example, the emphasis as to what makes a good and moral character is different in different contexts. There is a contrast between the community values of African cultures that highlight the interests in the collectivity and those of the West that privilege individual self-interest.

From my longitudinal research on African Indigenous knowledge systems that date back to the 1980s I want to reflect further on the African Indigenous knowledges and particularly the engagement of proverbs as epistemology. These reflections go beyond the specific study in these two African communities. There are particular issues that have become clear in the study of proverbs. First, proverbs go beyond their literal, superficial meaning to encompass deeper metaphorical meanings. While the simple literal interpretations may assist in communication it is art in itself to decipher the deeper embedded meanings [metaphorical] of proverbs in order to understand the importance of these knowledge systems. It is primarily the metaphorical meanings that Elders wish to illustrate when they share proverbs with youth. As the metaphorical meanings are often hidden within the proverb, the ability to understand the metaphorical meaning is often a testament to the wisdom and wit of the Elder. This is why most proverbs begin with the saying "As our Elders have said...". This also speaks to the general understanding that proverbs are "wise sayings". 
Second, proverbs speak to relationships to the local area and are deeply connected to the natural and social environment. Yet, within the proverbs, are also important educative lessons that transcend geographical boundaries. Effective research into Indigenous African proverbs and folktales must commence in the rural areas where culture and tradition are lived and practiced to their fullest. It is thus important to understand the context in which proverbs are spoken. Proverbs are appropriate in given contexts and situations. Some proverbs can be said to be restricted in their use and many not uttered by the young in the presence of chiefs and Elders whereby cultural custodians have that knowledge and power to share particular these proverbs. While many would assert that anyone can be conversant in proverbs, to be truly conversant in proverbs means knowing the contexts and situations in which proverbs are spoken and the meanings implied so as not to offend tradition and authority.

Furthermore, there is a sort of unwritten social sanction, regulation and care around the use and interpretation of proverbs to prevent the abuse and misappropriation for unintended purposes. Society bestows wisdom, knowledge and intelligence on one whose speeches are laced with proverbs but also easily frowns on someone who shows some arrogance and pomposity in their display of knowledge of these wise sayings. Traditional Elders and cultural custodians are generally expected to be wise people who are able lace their speeches with proverbs as illustrative of their key messages without their speeches being long and windy.

Third, with time a number of proverbs have been corrupted and given the dynamism of culture such proverbs have become transformed to move with the times. This is hopeful as no knowledge or tradition is static. But caution must also be exercised so that in transformation of these proverbs, they continue to maintain their true and intended meanings. There are also power dimensions of Indigenous proverbs that must be addressed such as custodianship, as well as the gender, age and ethnic dimensions of such knowledges. While it is said that anyone can speak and use proverbs, authority on Indigenous proverbs is often assigned to local custodians and Elders who are largely but not exclusively males. Ethnic, class, age, linguistic differences are important and speak to the heterogeneity of culture and traditions in a given community. While anyone irrespective of their age can speak and use proverbs, age-wise proverbs are associated with Elders' speech and recognition is given to this position of Elders when they are referenced in the use of proverbs. The young seek permission of the Elders to utter a proverb. In front of Elders, the youth must be careful that he or she fully understands the import of a proverb before uttering it. The misapplication of, or the improper use of proverbs is an insult to the wisdom of the Elders.

In addition, there are specific gender and sexual dimensions of proverbs. It is important for a researcher to understand how local understandings of gender infiltrate social knowledge and perceptions held by subjects. For example, proverbs, songs, folktales about traditional division of labour, sharing of family wealth and property etc. all speak to questions of gender. It is also observed that while proverbs are for everyone, men are generally laced with proverbs more so than women. In my experience at the palace, I have not seen many women appear before the court speaking in proverbs in the same way as the older men. This is not to say that women are not knowledgeable in proverbs; there are a number of older women who are adept at local proverbs. Yet, what this indicates is that we must question whether there is 
an unwritten social regulation in the use of proverbs that create this gendered dimension? There have also been sexual proverbs found in most communities studied. A number of proverbs have sexual connotations and offer very important lessons. The gender and gendered dimensions of proverbs thus may speak to the sexual content and the ways patriarchal nature of African societies can position women in terms of social status, roles and traditional/familial expectations.

On the question of ethnicity, given that local proverbs also speak about surrounding environments and use resources in the vicinity to make such cultural expressions, it is clear that while proverbs and the intended messages around responsibility, community solidarity, character building, moral training, etiquette etc may be shared across ethnic spaces, one can discern differences in the vocabulary. This also points to the importance of understanding the local language in which proverbs are spoken. While there is pedagogic and instructional value in making proverbs easily accessible, we must note that translations into other languages always run the risk of losing the deeper cultural meaning and social contexts within which proverbs are understood.

Many Elders, parents and cultural custodians see education of proverbs, fables, cultural stories, songs and folktales as one way to resurrect local and Indigenous languages. The power of language in the study of proverbs thus lies in its connection to culture and to the fact that it is language that actualizes the culture of a people. It is language that helps give an identity to a people. Language makes a civilization and a humanity. Without a language, a people are stripped of an identity, culture and sense of self, collective and history. Hence language is about social power. The claiming of language as identity makes for the authenticity of the local subject.

The issue of language is critical to understanding Indigenous proverbs, songs and riddles. This is important and calls for local partnerships and extended stay for research. Though true that something is lost in translation from local languages to English, we must also recognize that the act of writing also initiates a form of loss. In translating the mind and soul unto paper, something is indeed lost. As local knowledges and Indigenous languages are being lost; it is crucial that such knowledge must be preserved. Preservation of local languages and knowledges may involve the invitation of Elders into schools, lectures by Elders and the audio recording of conversations to be stored for future use. If Elders are to engage in these forms of education at the formal level then there must also be ways to sustain both these Elders and their process of knowledge production and delivery.

Se we must critically question why these knowledges are being lost in the first place. Beyond death and old age, our Indigenous language are being discarded and not spoken; school curriculum has not found a way to integrate these knowledges in the teachings of learners. The traditional forums for the production and dissemination of such knowledges have been destroyed and no longer en vogue. There have not been appropriate forums for the teaching, learning and communication of such knowledges to the young learner. The 'ownership' of intellectual and cultural property is a fundamental issue to be addressed as it speaks to how we credit the sources of such knowledge in research and how cultural custodians and Elders 
receive the recognition they deserve. In collaborative research it also becomes important to recognize the work of local scholars who document such proverbs given their knowledge of the local vernacular.

There is the question of the role of spirituality in education. Embedded in the study of Indigenous African proverbs is the acknowledgment of a peoples' spirituality. Spirituality is relevant to a people's existence. Spirituality in this context includes understandings of human relations with the Divine Being and Creator, Mother Earth and the Land, the understanding of land teachings, the development of a sense of self and the collective, as well as the meaning of social existence and a higher purpose in life. Educating the contemporary learner must engage all aspects of their identities, race, ethnicity, gender, class, [dis]ability, language, culture and spirituality. Learners bring their spiritual identities to the classroom whether it is acknowledged or not. Through the teachings of proverbs, it becomes easier to broach the subject of spirituality as understood broadly beyond the self to broader questions about relationships to a Creator, Mother Earth and the Land, communities, humility, respect of self, peers, Eldership and the power of reciprocal relations.

In conclusion, it can be reiterated that resolving the tensions around the pedagogy of different epistemologies such as proverbs, folktales, riddles, cultural stories and songs can be 'teachable moments' for youth as they navigate the challenges of everyday social existence. Proverbs communicate about the power of Eldership and ancestralism in the African social structure. Proverbs also reveal the complexity of Africa thought found in cultural idioms about social identities, spiritualities, communities and politics. Educators must be able to account for any continuities and discontinuities in local proverbs as Indigenous philosophies. These bodies of knowledge are passed down from generation to generation and while their meanings are encoded in local cultures, proverbs also are dynamic in responding to changing times. The context for the use of proverbs may change and local peoples may reinterpret these proverbs to suit situations with which they are confronted. Through proverbs, fables, riddles, cultural songs, stories and folktales the young are educated to come to a consciousness of self, peers, family, community and society. Such proverbs in particular can be said to constitute the consciousness of ethical responsibility. Proverbs provide an occasion or context to acknowledge the power of cultural memories as heritage knowledge, sites of intimate knowledge, and memories as transformative.

\section{Notes}

1. The selected proverbs are also used by other Nigerian ethnic groups such as Hausa Yoruba, and Edo (see Akporobaro, \& Emovon, 1994). Nigerian Proverbs: Meanings and Relevance Today. Lagos: Dept. of Culture, Federal Ministry of Information and Culture).

\section{References}

Abdi, A., \& Cleghorn, A. (Eds.). (2005). Issues in African Education: Sociological Perspectives. New York: Palgrave Macmillan.

Abrahams, R. (1967). On Proverb Collecting and Proverb Collection. Proverbium, 8, 181-184. 
Abrahams, R. (1968a). A Rhetoric of Everyday Life: Traditional Conversational Genres. Southern Folklore Quarterly, 32, 44-59.

Abrahams, R. (1968b). Introductory Remarks in a Rhetorical Theory of Folklore. Journal of American Folklore, 81, 143-158.

Abrahams, R. (1972). Proverbs and Proverbial Expression . In D. Richard (Ed.), Folklore and Folklife (pp.117-127). Chicago: Chicago University Press.

Abubakre, R. D., \& Reichmuth, S. (1997). Arabic Writing between Global and Local Culture: Scholars and Poets in Yorubaland. Research in African Literatures, 28(3), 183-209.

Akporobaro, F. B. O., \& Emovon, J. A. (1994). Nigerian Proverbs: Meanings and Relevance Today. Lagos: Dept. of Culture, Federal Ministry of Information and Culture.

Bascom, W. (1965). The Forms of Folklore: Prose Narratives. Journal of American Folklore, $78(307), 3-20$.

Battiste, M. A., \& Henderson, J. Y. (2000) Protecting Indigenous Knowledge and Heritage: A Global Challenge. Saskatoon: Purich.

Bishop, R. (1999). Collaborative Storytelling: Meeting Indigenous Peoples' Desires for Self-Determination in Research. In Indigenous Education around the World: Workshop Papers from the World Indigenous People's Conference: Education (Albuquerque, New Mexico, June 15-22, 1996).

Boateng, F. (1990). African Traditional Education: A Tool for Intergenerational Communication. In. M. K. Asante \& K. W. Asante (Eds.), African Culture: The Rhythms of Unity (pp.109-122). Trenton: African World Press.

Chamberlain, T. (2003). If this is Your Land, Where are Your Stories? Finding Common Ground. Alfred A. Knopf Canada.

Clifford, J. (1986). On Ethnographic Allegory. In J. Clifford \& G. E. Marcus (Eds.), The Poetic and Politics of Ethnography: Experiments in Contemporary Anthoropology (pp. 98-121). California: University of California Press.

Cole, M. (1992). Context, modularity, and the cultural constitution of development. In L.T. Winegar \& J. Valsiner (Eds.), Children's development within social context; Vol. 2: Research and methodology (pp. 5-31). Hillsdale: Lawrence Erlbaum Associates.

Cole, M. (2006). The Fifth Dimension: An after-school program built on diversity. New York: Russell Sage.

Dei, G. J. S. (2010). Reclaiming Indigenous Knowledge Through Character Education: Implications for Addressing and Preventing Youth Violence. A Final Report submitted the Literacy and Numeracy Secretariat (LNS), Ministry of Education, Ontario. February 1, 2010. [with the assistance of Jagjeet Gill, Camille Logan Dr. Meredith Lordan, Marlon Simmons and Lindsay Kerr]. 


\section{Macrothink

Dei, G. J. S. (2012). 'Suahunu': The Trialectic Space. Journal of Black Studies, 43(8), 823-846. http://dx.doi.org/10.1177/0021934712463065

Dei, G. J. S. (2013a). Integrating African Proverbs in the Education of Young Learners: The Challenge of Knowledge Synthesis. In. P. Sillitoe \& S. Heckler (Eds.), The Collaborative Moment: The Implications of Indigenous Studies for an Engaged Anthropology. London: Durham University Press.

Dei, G. J. S. (2013b). African Indigenous Proverbs and the Question of Youth Violence: Making the case for the Use of the Teachings of Akan Proverbs for Canadian Youth Character and Moral Education" Journal of Alberta Education Research [forthcoming].

Dei, G. J. S. (Ed.). (2011). Indigenous Philosophies and Critical Education. New York: Peter Lang Publishers.

Dorson, Richard (Ed.). (1972). Folklore and Folklife. Chicago University Press.

Eastman, C. A., \& Nerburn, K. (Eds.). (1993). The Soul of an Indian and Other Writings from Ohiyesa (The Classice Wisdom Collection). New World Library.

Firth, R. (1926). Proverbs in the Native Life with Particular Reference to those of the Maori. Folklore, 37, 134-153. http://dx.doi.org/10.1080/0015587X.1926.9718354

Geertz, C. (1993). Local Knowledge: Further essay in interpretive anthropology. London: Fontana Press.

Haig-Brown, C. (2003). Creating Spaces: Testimonio, Impossible Knowledge, and Academe. Qualitative Studies in Education, May-June 16(3), 415-433. http://dx.doi.org/10.1080/0951839032000086763

Johnson, B. (1993). Ojibway Tales. Nebraska: University of Nebraska Press

Johnson, B. (2003). Ojibway Heritage. Toronto: McClelland and Stewart.

Kalu, O. U. (1991). Gender Ideology in Igbo Religion: The Changing Religious Role of Women in Igboland. Africa / Istituto Italo-Africano, 46(2), 184-202.

Kudadjie, J. N. (1996). Ga and Dangme Proverbs: For Preaching and Teaching. Accra: Asempa Publishers. Retrieved on May 20, 2005, from www.afriprov.org/ebooks/gadangme.htm

Miruka, O. (2005). Encounter with oral literature. Nairobi: East African Educational Publishers.

Ogede, O. S. (1993). The Role of the Igede poet Micah Ichegbeh's 'Adiyah' Songs in the Political and Moral Education of his Local Audiences. African Languages and Cultures, 6(1), 49-68. http://dx.doi.org/10.1080/09544169308717761

Opoku, K. A. (1975). Speak to the Winds: Proverbs from Africa. New York: Northrop, Lee \& Shepard Co.

Opoku, K. A. (1997). Hearing and Keeping. Akan Proverbs. Accra: Asempa Publishers. 
Oyewumi, O. (1997). The Invention of Women: The Making an African Sense of Western Gender Discourses. Minneapolis: University of Minnesota Press.

Pachocinshi, R. (1996). Proverbs of Africa: Human Nature in the Nigerian Oral Tradition: An Exposition and Analysis of 2,600 Proverbs from 64 Peoples". Continuum International Publishing. $\quad$ Retrieved from http://www.paragonhouse.com/catalog/product_info.php?cPath=23_46\&products_id=155

Rogoff, B. (1981). Schooling and the development of cognitive skills. In H. C. Triandis \& A. Heron (Eds.), Handbook of cross-cultural psychology: Vol 4: Developmental Psychology (pp. 233-294). Rockleigh: Allyn and Bacon.

Rogoff, B. (2003). The cultural nature of human development. New York: Oxford University Press.

Tappan, M. B. (2006). Moral functioning as mediated action. Journal of Moral Education, 35(1), 1-18. http://dx.doi.org/10.1080/03057240500495203

Taylor, A. (1934). Problems in the study of proverbs. Journal of American Folklore, 47, 1-21.

Wanjohi, G. J. (2001). Under one roof: Gikuyu proverbs consolidated. Kenya: Paulines Publications Kenya.

Wanjohi, G. J. (2008). The wisdom and philosophy of African proverbs: The Gikuyu World-view. Kenya: Nyaturima Publications.

Wertsch, J. V. (1985). Vygotsky and the social transformation of mind. Cambridge: Harvard University Press.

Wertsch, J. V. (2002). Voices of Collective Remembering. Cambridge: Cambridge University Press.

Wolfgang, M., \& Dundas, A. (1981). The Wisdom of Many: Essays on the Proverb. New York. Garland Publishing

Yankah, K. (1989). The Proverb in the Content of Akan Rhetoric: a Theory Proverb Praxis. Bern, Frankfurt au Main: Peter Lang.

Yankah, K. (1995). Speaking for the Chief: Okyeame and the Politics of Akan Oratory. Bloomington \& Indianapolis: Indiana University Press.

\section{Copyright Disclaimer}

Copyright reserved by the author(s).

This article is an open-access article distributed under the terms and conditions of the Creative Commons Attribution license (http://creativecommons.org/licenses/by/3.0/). 